\title{
Speculation, philosophy and the end of religion: Save the name 'God' and the folly of this name as the queen of the sciences or the jester of academia
}

\begin{tabular}{|c|c|}
\hline \multicolumn{2}{|c|}{$\begin{array}{l}\text { Author: } \\
\text { Johann-Albrecht Meylahn }{ }^{1}\end{array}$} \\
\hline \multicolumn{2}{|c|}{ 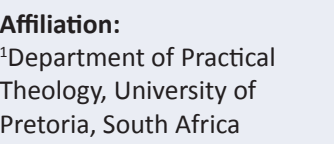 } \\
\hline \multicolumn{2}{|c|}{$\begin{array}{l}\text { Correspondence to: } \\
\text { Johann-Albrecht Meylahn }\end{array}$} \\
\hline \multicolumn{2}{|c|}{$\begin{array}{l}\text { Email: } \\
\text { jmeylahn@lantic.net }\end{array}$} \\
\hline \multicolumn{2}{|c|}{$\begin{array}{l}\text { Postal address: } \\
\text { PO Box 14885, Lyttelton } \\
\text { 0140, South Africa }\end{array}$} \\
\hline \multicolumn{2}{|c|}{$\begin{array}{l}\text { Dates: } \\
\text { Received: } 29 \text { Oct. } 2012 \\
\text { Accepted: } 17 \text { Sept. } 2013 \\
\text { Published: } 17 \text { Apr. } 2014\end{array}$} \\
\hline \multicolumn{2}{|c|}{$\begin{array}{l}\text { How to cite this article: } \\
\text { Meylahn, J.-A., 2014, } \\
\text { 'Speculation, philosophy } \\
\text { and the end of religion: } \\
\text { Save the name "God" and } \\
\text { the folly of this name as } \\
\text { the queen of the sciences } \\
\text { or the jester of academia', } \\
\text { Verbum et Ecclesia } 35(1) \text {, Art. } \\
\# 811,6 \text { pages. http://dx.doi. } \\
\text { org/10.4102/ve.v35i1.811 }\end{array}$} \\
\hline \multicolumn{2}{|c|}{$\begin{array}{l}\text { Note: } \\
\text { This article was presented } \\
\text { at a conference, Thinking } \\
\text { the absolute: Philosophy, } \\
\text { speculation and the end of } \\
\text { religion, held at Liverpool } \\
\text { Hope University from } 29 \text { June } \\
\text { to } 01 \text { July } 2012 \text {. }\end{array}$} \\
\hline \multicolumn{2}{|c|}{$\begin{array}{l}\text { Copyright: } \\
\text { (C) 2014. The Authors. } \\
\text { Licensee: AOSIS } \\
\text { OpenJournals. This wc } \\
\text { is licensed under the } \\
\text { Creative Commons } \\
\text { Attribution License. }\end{array}$} \\
\hline \multicolumn{2}{|l|}{ Read online: } \\
\hline 口ifta & $\begin{array}{l}\text { Scan this QR } \\
\text { code with your } \\
\text { smart phone or } \\
\text { mobile device } \\
\text { to read online. }\end{array}$ \\
\hline
\end{tabular}

In this article, Meillassoux and Laruelle were brought into conversation with Derrida concerning contingency, temporality, non-philosophy and God. The conversation between Derrida and Meillassoux focused on their respective views on trace and radical contingency, which opened towards reflections on God as either divinology (Meillassoux) or the endless desertification of language (Derrida), thus saving the name 'God' and keeping the name safe. One cannot think this desertification of language, 'God', without a reflection on khōra. This opened a conversational space with Laruelle's non-philosophy. One of the major criticisms against Laruelle is that his non-philosophy has no worth in terms of the extra-philosophical (ethical, political or juridical) and the same could be said with regards to khōra and, specifically, Derrida's interpretation of khōra. Therefore Derrida's interpretation of khōra with its 'unilateral' relation to logos, the giving and receiving of khōra without giving and receiving anything and thus remaining indifferent, were brought into conversation with Laruelle's unilateral duality. This unilateral duality, although indifferent to philosophy, makes all the difference to logos and thus to philosophy. The question is: what place is given to khōra and/or non-philosophy within academia? Derrida's God can be interpreted as a kind of autodeconstructive divine violence or holy folly. What place is given to divine violence or holy folly within academia? What is the relation of non-philosophy to philosophy? Is it the non-foundational foundation that remains totally indifferent to philosophy as it does not engage in a dialectical relationship with philosophy and yet it is the theory or science of philosophy? Can academia afford to 'give place' to this holy folly, this non-philosophy, this khōratic theo-logic, but on the other hand, can it afford not to 'give place' to the queen and/or jester of academia?

\section{Introduction}

In this article, the thoughts of Meillassoux, Laruelle ${ }^{1}$ and Derrida will be brought into conversation with each other concerning correlationalism, radical contingency, the trace, temporality, nonphilosophy and God.

Quentin Meillassoux developed his idea of radical contingency in his book After finitude: An essay on the necessity of contingency (2008a), as well as in various essays, which have been translated into English $(2007,2010,2011)$. However, the gist of his argument will not be unpacked in this article as the focus will be on the conversation between Meillassoux, Derrida and Laruelle. Meillassoux places his idea of radical contingency ${ }^{2}$ or necessary contingency over against the tradition that he terms correlationalism which, as he argues, developed from Kant. Kant's argument that one cannot know the Ding-an-sich, but only as it is for-us, is the basis of correlationism and causal necessity (see Brassier 2007:16-18; Meillassoux 2010:3-5). One cannot know objects (reality) as they are in themselves as all one has access to and thus knowledge of are the concepts (for-us). Thus, reality remains unknowable directly (objects as they are in themselves: Ding-an-sich) as it can be known only via a concept (as the object is given for-us - conceptualised). Meillassoux questions the absolute necessity of concepts for knowing reality, which he calls correlationalism, and contrasts this with a new absolute necessity, namely that of radical contingency. He develops his argument using four major arguments. Firstly, he begins with the idea of the arche-fossil (Meillassoux 2008a, 2010; see also Brassier 2007) to challenge the absolute logical necessity of correlationalism on purely logical grounds proving rather the necessity for contingency. Then, in chapter four of After finitude he reformulates Hume's argument by presenting it as 'Hume's

Meillassoux and Laruelle were the main conversational partners of the conference on Thinking the absolute: Philosophy, speculation and the end of religion and thus the article brings these two into conversation with Derrida. Laruelle presented the keynote at the conference.

$2 . . .$. there is no reason for anything to be or to remain thus and so rather than otherwise ... Everything could actually collapse: from trees to stars, from stars to laws, from physical laws to logical laws; and this not by virtue of some superior law whereby everything is destined to perish, but by virtue of the absence of any superior law capable of preserving anything, not matter what, from perishing' (Meillassoux 2008a:53). 
problem' (Meillassoux 2008a:82ff.). Hume argued that pure reasoning a priori cannot prove that a given effect must always follow a given cause (see also Hallward 2011:131). Meillassoux (2008a) accepts this problem:

we cannot rationally discover any reason why laws should be so rather than otherwise, that is to say why they should remain in their current state rather than being arbitrarily modified from one moment to the next. (pp. 90-91)

Thus, Meillassoux (2008a) argues that according to Hume:

we must seriously maintain that the laws of nature could change, not in accordance with some superior hidden law - the law of the mutable constant governing all subordinate transformations - but for no cause or reason whatsoever. (p. 83)

Then he brings in his trump card from Cantor's transfinite set-theory (see Johnston 2011) as well as Deleuze and Bergson's theory of matter (Meillassoux 2007) to correlate the logical necessity of contingency with radical contingency scientifically observed in matter.

Hägglund (2011:116) challenges Meillassoux's argument by declaring that one can only argue for contingency on the basis of succession. In other words, if one wants to argue that ' $X$ ' is something that is radically contingent to ' $Y$ ', this can only be argued on the basis of a perception of time and time can only be understood as succession. For Hägglund, once you have the concept of time as succession then you need to take into consideration decay or destruction. If one interprets time as decay and destruction then, for Hägglund, Derrida's concept of the trace becomes a better model for thinking time and succession $^{3}$ than radical contingency. Although I agree with Hägglund that Derrida's notion of the trace is more useful with regards to interpreting succession and the flow of time than radical contingency, I do not agree with how Hägglund interprets Derrida's concept of time and I also do not want to lose Meillassoux's concept of absolute time (see Meillassoux 2008a:62), but not as an instant but rather as Divine violence or Lacanian ethical Act, to which I will return later.

Hägglund (2011:119) interprets the trace as a 'metatheoretical notion that elucidates what is entailed by a commitment to succession in either of these registers' (ontology, epistemology, or phenomenology). I would rather argue that the trace understood within the context of differance is a quasi-transcendental notion where there is nothing meta as there is no outside text (see Derrida 1997:158) and thus it is impossible to use Derrida's idea of the trace as a conclusive argument, such as Hägglund's does for his radical atheism. The trace is not only the becoming-space of time and the becoming-time of space (Derrida 1982:8), but the becoming of a Zeit-Spiel-Raum ${ }^{4}$ [time-play-space] without the possibility

3.1 will show that these arguments are untenable, since here can be no contingency without the succession of time, which entails irreversible destruction and rules out
the possibility of resurrection a priori ... I demonstrate that the conception of time the possibility of resurrection a priori ... I demonstrate that the conception of time
as dependent on the structure of "the trace" provides a better model for thinking temporality and contingency than the one proposed by Meillassoux' (Hägglund temporality

4.'Différance opens (not actively nor passively) the time-space or what Caputo referring to Heidegger might refer to as the Zeit-Spiel-Raum (Caputo 1993:30) (Meylahn 2011:196) of any final causes or arguments. The moment one would make such conclusive arguments, one would destroy the play and thus Derrida's concept of différance and trace cannot be employed either in a conclusive argument for theism nor atheism as it remains an inconclusive play of impossible possibilities.

\section{Beyond theism and atheism towards saving the name 'God'}

What is the difference between Derrida's play or contingency where what is (text or context), is opened by the coming of the impossible possibility, and Meillassoux's (2008b) divinology where anything is possible? ${ }^{5}$ Meillassoux's (2008b:269) radical contingency opens to the possibility of the classic theistic God in the future, as he says: '... I maintain that God could really come about in the future'. Derrida would not argue for the possibility of such a God in the future, but would argue that such a God already exists for Christian theists today and that such a notion is as much possible as it is impossible and thus no body can make a conclusive judgement about the possibility or impossibility of such a God as all we have is the text, the name, and what is beyond the text is beyond our ability to make conclusive judgements about (see Caputo 2011).

Derrida's God is not the future possible God of radical contingency, nor is his God the God of theism, but for that matter it is also not the non-God of radical atheism, but all there is of God for Derrida is saving the name, 'God'. The name 'God' is saved (safe the name) as the endless desertification of language (Derrida 1995a:56). What this saved name signifies is beyond conclusive statements, it remains in the play of the Zeit-Spiel-Raum of différance. In Derrida's desertification, God's name is saved and is safe from any Idolatry in the form of conclusive knowledge as either theism or radical atheism. Likewise, Derrida's God is saved from Meillassoux's divinology (2008b) as a possible God, as such a possible God will be haunted by the trace (faint memory of a past never present and a future always still to come) and thus remain both possible and impossible, always haunted by a trace of a past never present and a future always still to come (see Derrida 1982:12, 21).

Derrida's name of God is thought as the infinite desertification of language, or one could say the infinite desertification of thought, which can also be stated as radical contingency or the arbitrariness of the sign, which Derrida upholds, but adds that the arbitrariness is not capricious (Derrida 1997:46). Laruelle (2010a) argues that Derrida's différance in its two modes ${ }^{6}$ is not absolutely contingent, as the two modes of différance are thought together in the greater project of deconstruction. I would argue that deconstruction takes place in the text and contexts and thus does not take place

5.See the critique of Meillassoux by Peter Hallward (2011).

6.Différance and the trace can be thought in two modes as both an economic and uneconomic and, for Derrida (1982:19), these two modes cannot be thought together. Yet Laruelle (2010a:ch 5) argues that although he says they cannot be thought together, he thinks them together: "But according to what "superior" thought together, he thinks them together: "But according to what "superior"
relation are the economy and the an-economy of Difference adjoined in order to relation are the economy and the an-economy of Difference adjoined in order to
form the unity-nonetheless of Deconstruction?'. 
in the objective world, but that it is a relation of non-relation that is presupposed by Derrida. Laruelle describes decisionalphilosophy or philosophy of difference, including Derrida, as a relation between ' $\mathrm{X}$ ' (relation) and ' $\mathrm{Y}$ ' (non-relation) (Brassier 2003:27). To this decisional-philosophy, Laruelle proposes a non-philosophy as a non-relation of relation and non-relation (Brassier 2003:27).

Therefore, although Derrida argues that all there is is text, or that there is no outside text (Derrida 1997:158), différance and the trace are ways of thinking this non-relationship between text and what is beyond text: the Other as the Other is presupposed. It is not correlationism in the strict sense, as Derrida nowhere argues that reality is structured like différance or like the trace, but that différance and the trace are what happen within texts. Yet, Derrida's thoughts concern the Other, as he himself says in an interview with Kearney (Kearney 1984:123-124), or as Caputo argues that what impassions Derrida's work is the other of language that cannot be shaken loose from language: différance (see Caputo 1997:17).

I argue that Laruelle's non-philosophy is a radicalisation of Derrida's famous statement: there is no outside text (Derrida 1997:158), there is no outside thought - there is only the One and the Vision-in-One (Laruelle 1999:140). One could say that it is a way of making peace with the fact that there is no outside text and of putting the haunting ghosts to rest. The question is: can these ghosts be put to rest? Meillassoux (2008b) seeks to put certain unredeemed ghosts to rest with his idea of a possible theistic God to come, Derrida's ghosts never come to rest but continue to haunt ad infinitum, whilst Laruelle is not concerned with ghosts but with what is, namely an axiomatic utterance of matter itself (see Brassier 2001a:183ff.). 'It is a question of positing the non-theitic root of decision axiomatically, without presupposing it via decision' (Brassier 2003:28). Laruelle is not concerned with the ghosts of correlationism that haunt all texts, but is concerned with the text as that is all that is. This is to say that any thinking or reflection or contemplation of the relation of thought or language or text with its other is still a thought or language or text. Non-philosophy is concerned with what is posited without presupposition on the basis of philosophical decision (see Brassier 2001b:68-69) and thus it is occasioned by philosophical decision. To put this in terms of the Christian narrative, there is no way to the Father but through Christ (Jn 14:6) or in the words of Christ, 'I am in the Father and the Father is in $\mathrm{me}^{\prime}$, so anyone who has seen Jesus, has seen the Father (Jn 14:8-11). In other words, there is a complete identification between Father and Son, so much so that the Father, as transcendental Other, no longer haunts the Son. There is no longer the Other that haunts différance and the trace: all there is, is trace or différance, and what there is should be seen as One or Vision-in-One, as mixture or Identity in the-last-instance or as Chesterton's two faces of God (see Žižek 2009:42). The Vision-in-One of the Ding-ansich as well as the for-us can be axiomatically stated, as in: 'I am the way and the truth and the life and nobody comes to the Father except through me' (Jn 14:6). Žižek (2009) argues:
The only solution is, as we have already seen, the very redoubling of alienation, the insight into how my alienation from the Absolute overlaps with the Absolute's self-alienation: I am 'in' God in my very distance from Him. (p. 55)

Or a double kenosis where both the Ding-an-sich as well as the for-us is sublated in a Vision-in-One.

\section{Non-philosophy}

Derrida's ideas of the Other via the trace as a haunting of the text would still be a thought, would still be writing and thus a reflection of the relationship between thought and its Other, even if that relationship would be thought of as a nonrelationship, but this reflection of the non-relationship is still thinking. Therefore, Laruelle (2010a) understands Derrida as presupposing a body-without-writing. Yet, even if it is only a presupposition and nothing is ever said about this bodywithout-writing, it is presupposed and that presupposition is already a thought that thinks the impossible possible relationship between text and its Other, even if that Other is absolutely other. That non-relationship is still thought as a relationship, or the abyss is still thought as abyss, and therefore there is a degree of correlation even if that correlation is thought as abyss and non-relation.

That which is presupposed (reality) is already thought as presupposed. Presupposing also happens in thought as it is not something external to thought. Laruelle's (2010a) radicalisation of there is no outside-text exposes the circular nature of decisional philosophy and exposes that Derrida's différance is, in the final analysis, still a decisional philosophy of difference. Derrida's philosophy of différance leads him into various aporias, yet it is exactly in these aporias: conditional(?)-unconditional, relation-non-relation, economic-uneconomic, decision-non-decision, that become the site for Laruelle's non-philosophy as his non-philosophy is anchored ${ }^{7}$ in this Zeit-Spiel-Raum of différance or trace.

I argue that Laruelle's non-philosophy is a radicalisation of Derrida's différance, or as Laruelle would probably argue, it is not a radicalisation or a revolution of différance, but rather the heresy of an axiomatic utterance on the basis or on the occasion of différance (see Brassier 2003:24). It is as heretical and blasphemous as the statement: 'I am the way and the truth and the life' (Jn 14:6).

If all there is is text or a-signifying utterance, that text is, for Derrida, in the Zeit-Spiel-Raum of différance or trace that relates it as a non-relation to the Other, whilst, for Laruelle (1999:143), the Zeit-Spiel-Raum and the text are equally immanent in thought and thus are identical in the lastinstance and given in-One or Vision-in-One. If they are given in-One, then there is nothing conclusive to say about it and one should then rather work with what is: the utterance, just

7. This non-thetic or immanently performative thought anchors itself in the nonreflexive root of decision by positing it axiomatically as its own enabling condition rather than trying to grasp it decisionally and failing (it is this failure which results in rather than trying to grasp it decisionally and failing (it is this failure which results in
the aporetic characterization of decision's non-thetic root as unthinkable caesura or obstacle to conceptualization)' (Brassier 2003:28). 
as the scientists work with their material, ${ }^{8}$ without worrying about how that which is, appeared, but taking what is as is that is truth no longer, adequation with correspondence, but adequation without correspondence (Brassier 2003:29).

If all one has is text, if all there is is thought, well then let us take thought seriously, or let us make peace with thought and stop worrying about that which one cannot know: namely the correlation between thought and reality. That is why, instead of Derrida's sign (as différance), Laruelle posits a radical-hyle which is a non-conceptual symbol (Brassier 2001a:267-268).

The radical-hyle is not a supplement ${ }^{9}$ like Derrida's sign, as it is related to reality via the aporia (absence-presence or remedy-poison of the pharmakon ${ }^{10}$ ), which is an impossiblepossible relation, but as non-relation still relation. The radical-hyle is a non-conceptual symbol. Différance remains undecidable (impossible possibility) and, in its undecidablity, remains bound to the metaphysical opposition even if it is transformed into a quasi-transcendental. The radical-hyle on the other hand is a non-name (non-concept), like différance, but 'the Identity of the radical-hyle as non-conceptual symbol is that of the non-Decidable as already decided determinant for the undecidable différance between signifier and signified' (Brassier 2001a:273). These words, non-conceptual symbol or utterance without statement (Brassier 2001a:267-268, 272273), remind one of khōra which is neither logic nor myth (Derrida 1995b:90, 117).

There are numerous similarities between non-philosophy and Derrida's (1995b) interpretation of khōra. Khōra has been described as both the mother and nurse, but it is not a name or a non-name, but that in which naming is possible. There is a similarity between the radical-hyle as a given without givenness (see Laruelle 2000:185) and khōra as a non-place that gives place in order to receive place (Meylahn 2013:259). For Laruelle (2000), the radical-hyle is the first name of matter; for Caputo (1997:40), khōra is the last name (surname) of différance. An important difference is that khōra is a non-mythological, non-logical attempt to speak about that which is beyond: epekeina, whilst the radical-hyle is the first name of that which is axiomatically stated.

Yet, on the other hand khōra can also be interpreted as the receptacle, the nurse, mother of that which is, that is, thought or language in which that which is comes to be without being given and without being received. In other words, khōra might be exactly the first name of what is axiomatically uttered (Brassier 2001a:264ff.) rather than the last name of what is not: différance (see Caputo 1997:40).

I would like to link up with where I left the thoughts on Meillassoux between Derrida's infinite desertification of

8.'Correlatively it is the One-in-One that is the real content of the supposed identification of the scientific-mathematical and the ontological, and which constitutes the real or last-instance of presupposition for this identification' (Laruelle 2000:183).

9.Derrida, in his article, '... That dangerous supplement ...' (Derrida 1997:141-164).

10.See Derrida's interpretation of the Pharmakon in Dissemination (Derrida 1981:99f.). language and the saving of the name God with Laruelle's non-philosophy.

\section{Holy folly and the jester of academia}

It is in this khōratic site that God's name is saved as the name of this absolute desertification of language. It is a desert that can only be crossed in faith, but never with knowledge. Yet, Laruelle's non-philosophy does not wish to cross any desert in faith, it does not pray or wait for any Messiah. On the contrary, in Žižek's terms, the Messiah has already come and there is nothing to wait for. In other words, the future is already present. ${ }^{11}$

Therefore the text or context (différance khōra) is no longer haunted and plagued by the trace of the Other, but the Other and the text are seen in-One. The world is no longer seen as presupposed by philosophy, namely as objects knowable as conditioned, but 'rather as a world-thought mixture' (Alkon \& Gunjevic 2011:219). This world-thought is cloned, dualysed as a duality that is ultimately identical. It is a unilateral duality of world and thought that are ultimately identical, but they do not form a synthesis on the basis of some or other correlation, but identical only in the last instance (see Alkon \& Gunjevic 2011:219). This world-thought is no longer a duel with thought or concept or sign or supplement on the one side and the world or other or material on the other, but cloned as a unilateral duality, as an identity in the last instance turned not towards an Other, but unifacially brought into the unknown reality of the future (Alkon \& Gunjevic 2011:219). The world is given without givenness and this 'arrival is an "advent" that comes from nowhere and presents again what was already present, but now turned towards and into the invisible face of the Stranger-subject' (Alkon \& Gunjevic 2011:219-220). Or as Laruelle (2000) says it:

It (advent) emerges as the identity of a unique face without a 'face to face'. The World is 'facing', is in a state of 'facing', in the same way in which something is said to be living. (p. 186)

In this turning towards the stranger-subject, the given is estranged for it is 'identified with the unseen face - the solitary and unilateral face of the future, or of the present as it faces the future for the first time' (Alkon \& Gunjevic 2011:220). This solitude of unique facing transforms alterity itself as the 'Real' is more other than the Other, but differently because it is radical immanence (Laruelle 2000:187). The Advent is not more absolute than the philosophy-event, but more radical a future that cannot be anticipated according to established patterns or some or other conception of transformation or revolution. For Laruelle (2010b), Christ has become the model of non-religious suspension of reciprocal mediation or correlation and therefore it is a radical future, a future Christ (see Alkon \& Gunjevic 2011:219ff.).

Non-philosophy is not haunted by the ghosts of the past, nor by the ghost of the future. Non-philosophy is exposed,

11 .... weak forcing, the minimal torsion exacted upon philosophy that is ultimately no longer reversible but uni-directional, consequently a future' (Laruelle 2011:254). 
turned towards, unifacing, the Future Christ. This openness to the future or this radical future - is it not a kind of holy folly, as in the tradition of the salos (Meylahn 2013:321ff.)? The madness to be besieged not by the Other, but by the future or to be a stranger subject where the Other is absolute future and thus exposing, unifacially turning all that is to the future - not the future of what is to come, or prayed for, but the unidirectional, facing the future? Meillassoux's absolute time is the instant, but what if it was absolute time as future, but a future as non-decisional, unpredictable, unconditioned? And is such a unifacial turning not the madness of divine violence beyond decision (see Žižek 2008)? The breaking in of absolute time as future is an act of divine violence, a holy madness (folly) of non-decisional philosophy.

The question is: how does this non-philosophy or khōratic non-theologic relate to logic and to theology? Alkon and Gunjevic (2011) have already explored certain possible relations to theology, but how does it relate to science and philosophy (academia)? Theology was once the queen of the sciences on the basis of classical metaphysics. The philosophers of difference challenged classical metaphysics, but replaced it with another kind of metaphysics, so that Laruelle (2010a) argues that they never left metaphysics. Could non-philosophy be seen as a kind of theology, but not as the queen of the sciences but rather as court jester or holy fool (salos)? Is this jester, this holy fool, who is open, completely open and exposed, unifacially turned to the future, not exactly what the closed university and master discourses (see Lacan 1991) need: to be opened beyond their decisional circularity where the letter is always found or where it always arrives at its destination (see Lacan 1972:72)? In response to Poe's (2008) short story, The purloined letter, Lacan (1972) argues that the letter (communication) within a particular discourse always arrives at its destination. Should academia not be unifacially turned so that the letter only maybe and/or perhaps arrives at its destination, as Derrida argued in response to Lacan's interpretation of Poe's, The purloined letter (Derrida 1975); or even more radical - never arrives, because there is no destination as there is only a letter and its absolute future beyond decisional logic: nonphilosophy? If the letter is all there is, radically exposed to a non-decisional future, is that not divine violence? Is that not holy folly? To be exposed to a non-decisional future is not the same as an undecided future where there is the impossibility (aporia) of decision between various possible futures. A radical non-decisional future is not to be exposed to a myriad of possible futures, but it is the radically nondecisional future of future Christ - Word made flesh.

Therefore, this exposure to the future is not the hope and faith in democracy to come or justice to come as such hope and faith is decisional and, as such, it is (even if it is minimally so) correlational. The hope and faith is without content. It is not faith and hope in possible impossible correlation, but hope and faith purified of content, as unifacial exposedness to the future, as future. Thus, the letter is all there is. The letter is, but it is exposed to a non-decisional future (without destination) which has certain parallels, although also important differences, to Lacan's ethical Act, which is an act of love. ${ }^{12}$ This radical future to which the letter is exposed is radical faith and hope radically devoid of content, an exposure to future without destination, but a future Christ an incarnate word: text and/or letter - as all there is; the only certainty - sola Christus.

\section{Conclusion}

Thus, in this holy madness one is left with the three core elements of Pauline Christianity: faith, hope and love and the greatest of these is love (1 Cor 13:13). Can it be that the Christ narrative and thus Christian theology is exemplary with regards to this letter and thus can help in keeping this letter (incarnate word, radical immanence) safe from decisional philosophy? A letter exposed to the future Christ (incarnate word: text) as the only non-certain certainty that can only be received as a gift (sola gratia) in faith (sola fide). Christian theology, as the guardian of the incarnate word, has a place in academia as the queen who watches over text (the body not without writing, but the body as writing - as Logos made flesh, as crucified God).

As queen, theology invites the other disciplines to the table of communion where this body is shared between the sciences. Yet, she watches over this table or body or text with the open invitation, not as an imperial queen with veto power (final decision) but, if with any power at all, the power of the court jester, the holy fool absolutely exposed to the future Christ: a letter without destination, exposed to the future as letter: incarnate word, Sola Christus.

\section{Acknowledgements Competing interests}

The author declares that he has no financial or personal relationships that may have inappropriately influenced him in writing this article.

\section{References}

Alkon, G. \& Gunjevic, B., 2011, 'According to the identity of the Real: The nonphilosophical thought of immanence', Synthesis philosophica 51(1), 209-227.

Brassier, R., 2001a, 'Alien theory: The decline of materialism in the name of matter', unpublished PhD thesis, Dept. of Philosophy, University of Warwick.

Brassier, R., 2001b, 'Behold the non-rabbit: Kant, Quine, Laruelle', Pli: The Warwick Journal of Philosophy 12, 50-82.

Brassier, R., 2003, 'Axiomatic heresy: The non-philosophy of François Laruelle', Radical Philosophy 121, 24-35.

Brassier, R., 2007, 'The enigma of Realism: On Quentin Meillassoux's After finitude', in R. Mackay (ed.), Collapse II, pp. 15-54, Urbanomic, Oxford.

Caputo, J.D., 1993, Demythologizing Heidegger, Indiana University Press, Indianapolis.

Caputo, J.D., 1997, The prayers and tears of Jacques Derrida: Religion without religion, Indiana University Press, Indianapolis.

Caputo, J.D., 2011, 'The return of anti-religion: From radical atheism to radical theology', Journal for Cultural and Religious Theology 11(2), 32-125.

Derrida, J., 1975, 'The purveyor of truth', transl. W. Domingo, J. Hulbert \& M. Ron, Yale French Studies 52, Graphesis: Perspectives in Literature and Philosophy, 31-113.

Derrida, J., 1981, Dissemination, transl. B. Johnson, Continuum, New York. PMid:6910236

Derrida, J., 1982, Margins of philosophy, transl. A. Bass, Harvester, Brighton.

12.For Lacan, the true ethical Act is motivated by love and not law (Hurst 2008:329) see also: 'The domain of pure violence, the domain outside law or legal power, the domain of that violence which is neither law-founding nor law-sustaining, is the domain of love' (Žižek 2008:488). 
Derrida, J., 1995a, 'Sauf le nom', in T. Dutoit (ed.), On the name, transl. D. Wood, J.J. Leavey \& I. McLeod, pp. 35-88, Standford University Press, Stanford.

Derrida, J., 1995b, 'Khōra', in T. Duoit (ed), On the name, transl. I Mcloead, pp. 89-127, Stanford University Press, Stanford.

Derrida, J., 1997, Of grammatology, transl. G.C. Spivak, John Hopkins Press, Baltimore.

Hägglund, M., 2011, 'Radical atheist Materialism: A critique of Meillassoux', in L. Bryant, N. Srnicek \& G. Harman (eds.), The speculative turn: Continental Materialism and Realism, pp. 114-129, re-press, Melbourne.

Hallward, P., 2011, 'Anything is possible: A reading of Quentin Meillassoux's After finitude', in L. Bryant, N. Srnicek \& G. Harman (eds.). The speculative turn: Continental Materialism and Realism, pp. 130-141, re-press, Melbourne.

Hurst, A., 2008, Derrida vis-à-vis Lacan: Interweaving deconstruction and psychoanalysis, Fordham University Press, New York. http://dx.doi.org/10.5422/ fso/9780823228744.001.0001

Johnston, A., 2011, 'Hume's revenge: A dieu, Meillassoux?', in L. Bryant, N. Srnicek \& G. Harman (eds.), The speculative turn: Continental Materialism and Realism, pp. 92-113, re-press, Melbourne.

Kearney, R., 1984, 'Dialogue with Jacques Derrida', Dialogue with contemporary contintental thinkers, pp. 105-126, Manchester University Press, Manchester.

Lacan, J., 1972, 'Seminar on “The Purloined Letter"', transl. J. Mehlman, Yale French Studies 48, French Freud: Structural studies in Psychoanalysis, 39-72.

Lacan, J., 1991, Le séminaire, Livre XVII: L'envers de la psychanalyse, Jacques-Alain Miller (ed.), Seuil, Paris.

Laruelle, F., 1999, 'A summary of non-philosophy', Pli: The Warwick Journal of Philosophy (8), 138-148.

Laruelle, F., 2000, 'Identity and event', Pli: The Warwick Journal of Philosophy (9), Parallel processes, $174-189$.
Laruelle, F., 2010a, Philosophies of difference: A critical introduction to non-philosophy, transl. R. Gangle, Continuum, New York. Kindle edition.

Laruelle, F., 2010b, Future Christ: A lesson in heresy, transl. A.P. Smith, Continuum, London.

Laruelle, F., 2011, 'The generic as predicate and constant: Non-philosophy and materialism', in L. Bryant, N. Srnicek \& G. Harman (eds.), The speculative turn: Continental Materialism and Realism, pp. 237-260, re-press, Melbourne.

Meillassoux, Q., 2007, 'Subtraction and contraction: Deleuze, immanence, and matter and memory', in R. Mackay (ed.), Collapse III, pp. 63-107, Urbanomic, Falmouth.

Meillassoux, Q., 2008a, After finitude: An essay on radical contingency, transl. R. Brassier, Continuum, New York.

Meillassoux, Q., 2008b, 'Spectral dilemma', in R. Mackay (ed.), Collapse IV, pp. 261276, Urbanomic, Falmouth.

Meillassoux, Q., 2010, 'The contingency of the laws of nature', Environment and Planning D: Society and Space 30(2), 322-334. http://dx.doi.org/10.1068/d6210

Meillassoux, Q., 2011, 'Potentiality and virtuality', in L. Bryant, N. Srnicek \& G. Harman (eds.), The speculative turn: Continental Materialism and Realism, pp. 224-236, re-press, Melbourne.

Meylahn, J.A., 2013, The limits and possibilities of postmetaphysical God-talk: A conversation between Heidegger, Levinas and Derrida, Peeters, Leuven.

Poe, E.A., 2008, 'The purloined letter', in The Works of Edgar Allen Poe Volume 2 (of 5) of the Raven Edition, pp. 7-62, E-book, Project Gutenberg.

Žižek, S., 2008, In defense of lost causes, Verso, London.

Žižek, S., 2009, 'From Job to Christ: A Paulinian reading of Chesteron', in J.D. Caputo \& L.M. Alcoff (eds.), St. Paul among the Philosophers, pp. 39-58, Indiana University Press, Bloomington. 